\title{
To study the acceptance of epidural analgesia for painless labor at a tertiary care centre
}

\section{Neena Gupta ${ }^{1}$, Sachidanand Gupta ${ }^{2}$, Apurva Agrawal ${ }^{3}$, Shaily Agrawal ${ }^{1}$, Seema Diwedi ${ }^{1}$, Jyotsna $\operatorname{Singh}^{1}{ }^{*}$}

\author{
${ }^{1}$ Department of Obstetrics \& Gynecology, GSVM Medical College, Kanpur, Uttar Pradesh, India \\ ${ }^{2}$ Department of Anesthesia, Rama Medical College, Kanpur, Uttar Pradesh, India \\ ${ }^{3}$ Department of Anesthesia, GSVM Medical College, Kanpur, Uttar Pradesh, India
}

Received: 30 October 2014

Accepted: 10 November 2014

\section{*Correspondence:}

Dr. Jyotsna Singh,

E-mail: jyotsna.0805@gmail.com

Copyright: () the author(s), publisher and licensee Medip Academy. This is an open-access article distributed under the terms of the Creative Commons Attribution Non-Commercial License, which permits unrestricted non-commercial use, distribution, and reproduction in any medium, provided the original work is properly cited.

\begin{abstract}
Background: Epidural analgesia is a central nerve block technique achieved by injection of a local anaesthetic close to the nerves that transmit pain and is widely used as a form of pain relief in labor. Epidural analgesia is the most effective method of pain relief during labor. But unfortunately in India incidence of painless labor by epidural analgesia is very rare even in these days. The aim of our study was to study the acceptance of epidural analgesia at a tertiary care centre.

Methods: The present study was conducted in department of obstetrics and gynaecology UISEMH, Kanpur over the period from May 2012 to May 2013. The study was conducted on 98 patients who were counselled regarding the adoption of epidural analgesia as painless labour and out of these 50 patients opted for epidural analgesia.

Results: In our present study the acceptance was greater in primigravida $(72.43 \%)$ as compared to multigravida $(20 \%)$. In our society social reason was the common cause for non-acceptance in primigravida (87.5\%). The majority of patients belonged to middle socioeconomic status $(52 \%)$ and more number of educated patients opted for epidural analgesia.

Conclusions: It was found that increased awareness can lead to increased acceptance of epidural analgesia.
\end{abstract}

Keywords: Epidural analgesia, Painless labor, Acceptance

\section{INTRODUCTION}

Pregnancy and childbirth is the most precious gift for women given by God. The only thing which makes a pregnant lady curious, anxious and fearful is the pain during delivery. Labor pain has been described by most as the most painful experience a woman can have in her lifetime. Efforts have been taken for centuries to alleviate this labor pain. The methods of pain relief are nonpharmacological and pharmacological. The pharmacological methods of pain relief are inhalational analgesics, narcotics and epidural analgesia. Epidural analgesia is a central nerve blockade technique, which involves the injection of a local anaesthetic into the lower region of the spine close to the nerves that transmit painful stimuli from the contracting uterus and birth canal. The anaesthetic agent inhibits nerve conduction by blocking sodium channels in nerve membranes, thereby preventing the propagation of nerve impulses along these fibres. Blocking of painful stimulus from the nerves as they cross the epidural space results in analgesia, which should be apparent within 10 to 20 minutes of administration.

Unfortunately, in India incidence of painless labour by epidural is very rare even in these days due to several reasons. 
- Lack of information about painless labour to expected mothers and their family members.

- Socio economic reasons.

- Lack of proper set up including training of doctors and paramedical staff.

\section{METHODS}

This prospective study was conducted in upper India sugar exchange maternity hospital department of obstetrics and gynecology, GSVM Medical College, Kanpur, study was carried from May 2012 to May 2013. The study was conducted on 98 patients. The 98 patients were counselled regarding the adoption of epidural analgesia as painless labour and out of these 50 patients opted for epidural analgesia.

\section{Inclusion criterion}

Healthy patients with cephalic presentation, singleton pregnancy and 37-42 weeks gestation.

\section{Exclusion criterion}

Women with preeclampsia, diabetes, preterm labor, bleeding disorders, scoliosis, allergy to study drug, blood in CSF in epidural catheter.

\section{Statistical analysis}

The statistical significance of observed difference between control and study groups was determined by students ' $t$ ' test and 'chi square' test.

\section{RESULTS}

In our study, distribution of cases according to age groups showed that majority of patients belonged to age group $18-23,60 \%$ in study group and $50 \%$ in control groups. The maximum number of patients belonged to $37-40$ weeks of gestation in both the groups. The mean gestational age is 38.2 with a standard deviation of 1.3626. The majority of the patients belonged to middle socioeconomic status $(52 \%)$ in study group while maximum patients in control group were of low socioeconomic status. The educated patients opted more for epidural analgesia. Above mentioned socio demographic factors were compared between the two groups, but there was no statistically significant difference was found (Table 1).

Acceptance of epidural analgesia among primigravida was $72.4 \%$ while in multigravida it was low $(20 \%)$. The association is statistically significant (Table 2). Table 3 shows that social reasons were the main cause for nonacceptance of epidural analgesia in primigravida $(75 \%)$ while in multigravida, better pain tolerance was the main cause $(81.25 \%)$. Patients were asked about their awareness regarding methods of pain relief. Only 7 patients among $98(7.14 \%)$ were aware of epidural analgesia as method of pain relief and 55 (56.12\%) patients were aware of pain relief by injection (Table 4).

Table 1: Sociodemographic profile of study and control groups.

\begin{tabular}{|c|c|c|c|c|}
\hline \multirow{2}{*}{$\begin{array}{l}\text { Sociodemographic } \\
\text { parameters }\end{array}$} & \multicolumn{2}{|c|}{$\begin{array}{l}\text { Study group } \\
(\mathrm{n}=50)\end{array}$} & \multicolumn{2}{|c|}{$\begin{array}{l}\text { Control group } \\
(\mathrm{n}=48)\end{array}$} \\
\hline & $\mathbf{N}$ & $\%$ & $\mathbf{N}$ & $\%$ \\
\hline \multicolumn{5}{|l|}{ Age group (years) } \\
\hline $18-23$ & 30 & 60 & 24 & 50 \\
\hline $24-29$ & 18 & 46 & 21 & 44 \\
\hline $30-35$ & 2 & 4 & 3 & 6.3 \\
\hline$>35$ & - & - & - & - \\
\hline \multicolumn{5}{|c|}{ Gestational age (weeks) } \\
\hline $37-40$ & 47 & 94 & 43 & 89.6 \\
\hline$>40$ & 3 & 6 & 5 & 10.4 \\
\hline \multicolumn{5}{|c|}{ Socioeconomic status } \\
\hline Low & 22 & 44 & 27 & 56.3 \\
\hline Middle & 26 & 52 & 19 & 39.6 \\
\hline High & 2 & 4 & 2 & 4.2 \\
\hline \multicolumn{5}{|l|}{ Educational status } \\
\hline Primary & 5 & 10 & 3 & 6.3 \\
\hline High school & 8 & 16 & 7 & 14.3 \\
\hline Intermediate & 25 & 50 & 22 & 45.8 \\
\hline Graduate & 12 & 24 & 16 & 33.3 \\
\hline \multicolumn{5}{|l|}{ Gravida } \\
\hline G1 & 42 & 84 & 38 & 79.2 \\
\hline G2 & 7 & 14 & 8 & 16.7 \\
\hline G3 & 1 & 2 & 2 & 4.2 \\
\hline \multicolumn{5}{|l|}{ Residence } \\
\hline Urban & 37 & 74 & 35 & 72.9 \\
\hline Rural & 13 & 26 & 13 & 27.1 \\
\hline
\end{tabular}

Table 2: Acceptance of epidural analgesia for painless labour in a tertiary care centre.

\begin{tabular}{|lllll|} 
& $\begin{array}{l}\text { No. of pt. } \\
\text { counselled }\end{array}$ & $\begin{array}{l}\text { No. of pt. } \\
\text { opted for } \\
\text { epidural } \\
\text { analgesia }\end{array}$ & $\begin{array}{l}\text { No. of pt } \\
\text { not opted } \\
\text { for epidural } \\
\text { analgesia }\end{array}$ & $\begin{array}{l}\% \text { of } \\
\text { accepta } \\
\text {-bility }\end{array}$ \\
Primigravida & 58 & 42 & 16 & $72.4 \%$ \\
\hline Multigravida & 40 & 8 & 32 & $20 \%$ \\
\hline Total & 98 & 50 & 48 & $51.02 \%$ \\
\hline
\end{tabular}

Chi square $=26.02 ; \mathrm{P}<0.05$ which is significant

Table 3: Causes for non-acceptance of epidural analgesia.

\begin{tabular}{|llllll|}
\hline Causes & $\mathbf{N}=\mathbf{4 8}$ & \multicolumn{2}{l}{$\begin{array}{l}\text { Primigravida } \\
(\mathbf{n}=\mathbf{1 6})\end{array}$} & $\begin{array}{l}\text { Multigravida } \\
(\mathbf{n}=\mathbf{3 2})\end{array}$ \\
\hline Social & $\mathbf{N o .}$ & $\mathbf{\%}$ & No. & \% \\
\hline Economical & 16 & 12 & $75 \%$ & 4 & $12.5 \%$ \\
\hline Better pain tolerance & 28 & 2 & $12.5 \%$ & 2 & $6.25 \%$ \\
\hline
\end{tabular}

Chi square $=25.6 ; \mathrm{P}<0.05$ which is significant 
Table 4: Awareness about methods of pain relief in labour.

\begin{tabular}{|lllll|}
\hline \multirow{2}{*}{$\begin{array}{l}\text { Methods of pain relief } \\
\text { during labour }\end{array}$} & \multicolumn{3}{l}{ A wareness about methods } \\
\cline { 2 - 5 } & Present & \multicolumn{2}{l|}{ Absent } \\
\hline Pain relief by injection & 55 & $\mathbf{\%}$ & No. & \% \\
\hline Pain relief by epidural & 7 & 7.14 & 44 & 43.9 \\
\hline
\end{tabular}

\section{DISCUSSION}

Our study included 98 patients who were counselled for epidural analgesia as method of pain relief, out of which 50 patient opted for it. ${ }^{1}$ Most of the patient in both the groups belonged to the age group between 18-23 which is the age of maximum reproducibility and were primigravida this was in concordance with the study of Sheiner E et al. (2000), he concluded that epidural analgesia was recommended more to low parity and younger women, exhibiting more pain. ${ }^{2}$ While in the study of Hueston WJ et al. (1994) the use of intrapartum epidural analgesia was associated with nulliparity and higher maternal age. ${ }^{3}$ Our study shows distribution according to educational status, educated patients opted more for epidural analgesia, this was partially supported by the study of Morr AK et al. (2007) who found a marginal significant difference in the utilization of epidural analgesia in women with a higher educational degree. ${ }^{4}$

58 primigravida were counselled out of which 42 accepted the epidural analgesia and out of 40 multigravida 8 accepted. The acceptance of was higher in primigravida. ${ }^{2,3}$ Women's education about the epidural analgesia during the antenatal period can increase the acceptance. Goldberg AB et al. (1999) concluded that women who plan antenatally to receive epidural analgesics are strongly associated with her likelihood of receiving it. ${ }^{5}$ In our study, social reason was the common cause of non-acceptance of epidural analgesia among primigravida $(75 \%)$ while multigravida did not accepted due to better pain tolerance. Our studies were supported by the following study, Le Ray $\mathrm{C}$ et al. (2008) studied that unfavourable social situation and organizational factors are associated with the patients choice to give birth without epidural analgesia. The patients decision to deliver without epidural analgesia was closely associated with high parity, also more frequent among women in unfavourable social situation. ${ }^{6}$ Awareness regarding method of pain relief was very low, only 7 patients among 98 patients were aware of epidural analgesia as method of pain relief ,this was explained by the study of To WW (2004) which showed poor general awareness of pregnant women about the proper role of epidural analgesia in labor, leading to a low patient demand for such services. ${ }^{7}$

\section{CONCLUSION}

Here we conclude that increased awareness about epidural analgesia as a method of pain relief result in its increased acceptance, this is very clear from our study which shows that most of the patients did not know about it, thus there should be effort to educate the pregnant women during their antenatal visit regarding this method and its benefit, so that the anxiety and fear associated with child birth can be minimised.

\section{ACKNOWLEDGEMENTS}

The contribution of every author was appreciable along with the institution where study was conducted and all authors extend their sincere thanks to the patients who gave their consent for the inclusion in the study.

\section{Funding: No funding sources}

Conflict of interest: None declared

Ethical approval: The study was approved by the Institutional Ethics Committee

\section{REFERENCES}

1. Brownridge P. Treatment options for the relief of pain during childbirth. Drugs. 1999;41(1):69-80.

2. Scheiner E, Sheiner EK, Shoham-Vardi I, Gurman GM, Press F, Mazor M, et al. Predictors of recommendation and acceptance of intrapartum epidural analgesia. Anesth Analg. 2000 Jan;90(1):109-13.

3. Hueston WJ, McClaflin RR, Mansfield CJ, Rudy M. Factors associated with the use of intrapartum epidural analgesia. Obstet Gynecol. 1994 Oct;84(4):579-82.

4. Morr AK, Broscheit J, Blissing S, Bernar T, Dietl J. Influence of socioeconomic status on the utilization of epidural analgesia during labour. Z Geburtshlife Neonatol. 2007 Feb;211(1):23-6.

5. Goldberg AB, Cohen A, Lieberman E. Nulliparas' preferences for epidural analgesia: their effects on actual use in labor. Birth.1999 Sep;26(3):139-43.

6. Le Ray C, Goffinet F, Palot M, Garel M, Blondel B. Factors associated with the choice of delivery without epidural analgesia woman at low risk in France. Birth. 2008 Sep;35(3):171-8.

7. To WW. A questionnaire survey on patients' attitudes towards epidural analgesia in labor. Hong Kong Med J. 2007 Jun;13(3):208-15.

DOI: $10.5455 / 2320-1770$. ijrcog20141241

Cite this article as: Gupta N, Gupta S, Agrawal A, Agrawal S, Diwedi S, Singh J. To study the acceptance of epidural analgesia for painless labor at a tertiary care centre. Int J Reprod Contracept Obstet Gynecol 2014;3:1087-9. 